\title{
A REPORT ON THE PUDDLE (BLEATING) FROG OCCIDOZYGA LIMA (GRAVENHORST) FROM THE TEKNAF PENINSULA, BANGLADESH, WITH NOTES ON THE PRESENCE OF OTHER VERTEBRATES
}

\author{
Mohammad Ali Reza Khan
}

Dubai Zoo, P.O. Box 67, Dubai, United Arab Emirates.

(Ex-Associate Professor of Zoology, Dhaka University, Bangladesh)

Email:mark1147@emirates.net.ae;MAKHAN@dm.gov.ae

\begin{abstract}
On the basis of a six-day survey of southeastern Bangladesh Occidozyga lima appeared to be a common species in the Teknaf Peninsula. The most common amphibians of the region are the Cricket Frog Limnonectes limnocharis, Skipping Frog Euphlyctis cyanophlyctis, Ornate Narrow-mouthed Frog Microhyla ornata, Indian Bull Frog Hoplobatrachus tigerinus and Common Toad Bufo melanostictus. Two species of tree frogs Polypedates leucomystax and Polypedates maculatus are also common.
\end{abstract}

\section{Keywords}

Bangladesh, Puddle (Bleating) Frog, Occidozyga lima, sightings, call, Teknaf Peninsula, Cox Bazar

\section{Introduction}

During the last two decades few studies have been conducted on the amphibians of Bangladesh (Chowdhury, 1996; Husain \& Rahman, 1978; Khan, 1982, 1987, 1997). These reports have established the presence of some 20 species of amphibians in the country. It may be conjectured from the list of amphibians occurring in areas of India bordering Bangladesh (Deuti \& Bharati-Goswami, 1995), that there could be at least another five species raising Bangladesh's total to 25 species.

In 1994 I found several specimens of a hitherto unrecorded species of frog from a forest village in the Teknaf Peninsula of Bangladesh (Fig. 1). After subsequent visits and collection of specimens I became certain of the occurrence of the Puddle Frog Occidozyga lima in Bangladesh (Khan, 1997). This discovery was from a $10 \mathrm{~m}^{2}$ area by the side of a hillock, near a village Whykeong, within this Peninsula. It was natural to believe that this species could not have remained isolated in such a small pocket, so I planned to make a survey of the peninsula with a view to determining current status of this frog in the Peninsula. Emirates Natural History Group, Abu Dhabi agreed to support the project partially.

I made a four-day field study with the assistance of an amphibian biologist from Dhaka and two local villagers from Teknaf Peninsula. In addition, I had another two-day field trip in a northern forest at Sylhet and was assisted by two local residents. These field studies were very intensive and were made between 11 and 18 August 1999. These contained 110 hours of combined observations by two scientists, including one/ two helpers and myself. Out of these 94 hours were spent in Teknaf Peninsula and 16 hours at Sylhet.

There was torrential rain from 11-14 August when total rainfall was over $250 \mathrm{~mm}$ in the study area. The annual rainfall in the Cox's Bazar area is $3,558 \mathrm{~mm}$, average annual humidity 78.10 per cent and the minimum and maximum annual temperatures are between $13.3^{\circ}-24.4^{\circ} \mathrm{C}$ and $26.10^{\circ}-31.10^{\circ} \mathrm{C}$ respectively (Khan, 1982). There was nearly $40 \mathrm{~mm}$ of rainfall during 17 and 18 August in study area at Sylhet.

Continuous rain is generally good for amphibian searching as most species are out of their hiding places for breeding. However, rainy days are bad for noting other terrestrial vertebrates and birds. Also there was an explosion of the Brown Land Leech Haemadipsa zeylanica population as a result of the heavy downpour. We had to curtail our field study by two days as torrential rains had flooded a major portion of the study area.

\section{Study area}

The study area included Whykeong Forest Village and its neighbourhood environs of Teknaf Township and Rajar Chhara -- all parts of Teknaf Peninsula. A northeastern forest and a 


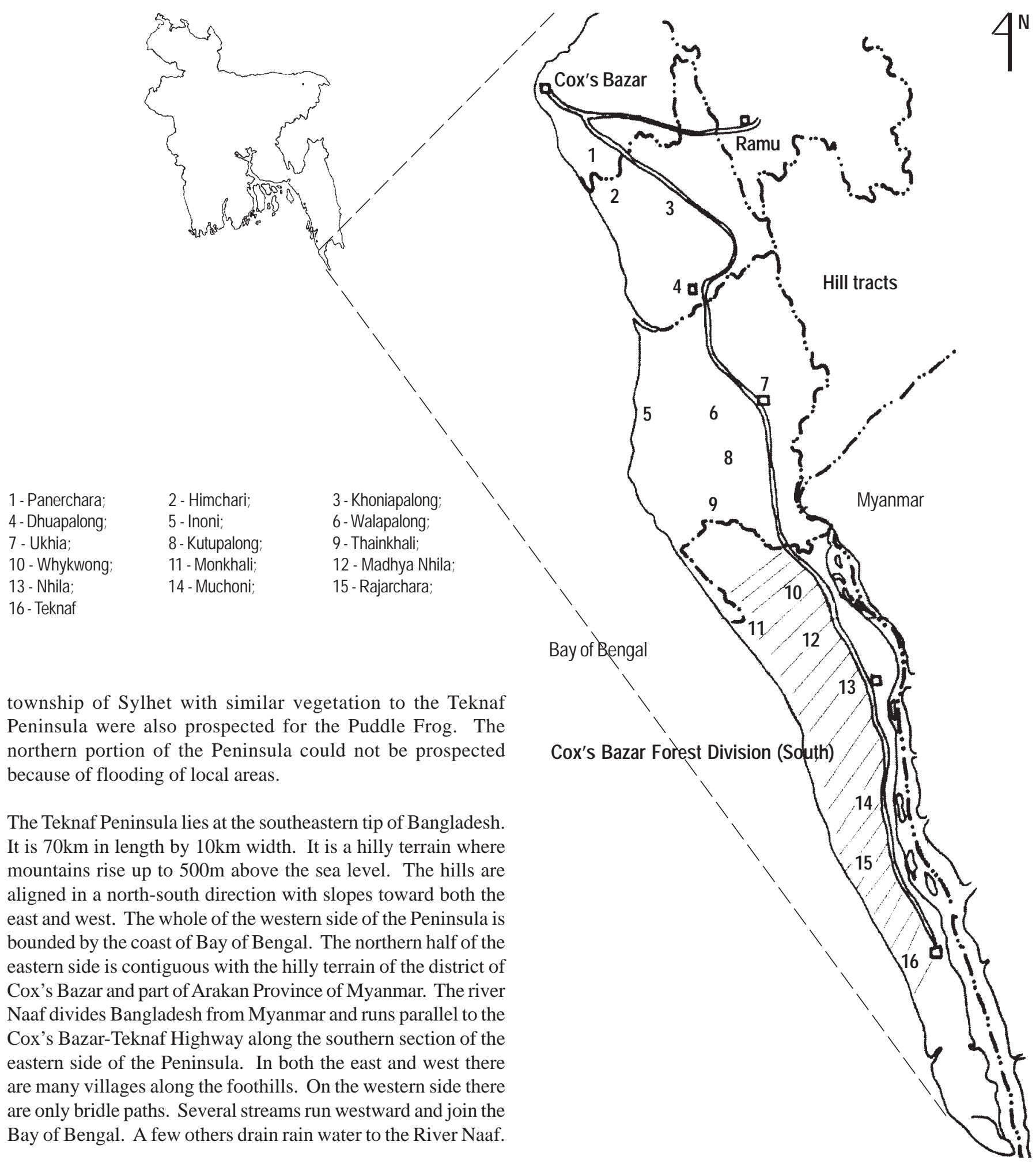

About half a century back the whole of the Peninsula was under cover of mixed evergreen forest dominated by several species of tall trees, e.g., Gurjan Balsam Dipterocarpus terbinatus, Wild Mango Mangifera longipes, Swintonia floribunda, Grand Apple Syzygium grandis, Hopea odorata, Figs Ficus spp. and

Figure 1. Map of the study area, Teknaf Peninsula of Bangladesh showing the distribution of Occidozyga lima 
Tall Jack Tree Artocarpus chaplasha - all over 20m in height. Remnants of these trees are still visible in some parts of the forest and villages bordering it. Nevertheless, these are not naturally growing but planted ones.

Due to bad forestry practices, primarily clear-cutting of trees (clear felling as termed by the government forest department), no natural forest persists in the whole area. As a part of the government policy of forestry management natural forests have been replaced with monocultures (single species cultivation) of Teak Tectona grandis, White Teak/Gamari Gmelina arborea, Syzygium grandis and Dipterocarpus spp. These species are commercially important. However, some areas of such plantations have overgrown with understory plants, thickets and liana that give the forest a deceptive look of a natural one.

In the Sylhet District forests include mixed-evergreen trees like the ones in Teknaf as well as moist deciduous trees like Sal Shorea robusta, Cassia spp., Albizia spp., Dillenia pentagyna, Macaranga indica, Artocarpus lakoocha and Terminalia spp. Undergrowth is nearly similar in both the Sylhet and Teknaf areas. This included several species of bamboo, canes, Talipot Palms Corypha elata and C. umbracaulifera, Indian Rhododendron Melastoma malabathricum, ground orchids, Cassia tora and C. sophora, Euphorbia sp., Mussaenda sp., Sensitive Plant Mimosa pudica, and tree ferns. Also there were grasses, small ferns and other pteridophytes and weeds.

Many streams and streamlets criss-cross the forest. Due to heavy rains all these were overflowing. Also the rainwater had accumulated in depressions giving rise to many temporary pools and puddles along the flatter portions of the hills.

\section{Methodology}

A minimum of three observers combed areas around the paths totalling over $20 \mathrm{~km}$ in all and many small, badminton court-sized flat areas with ground vegetation. Observations were made both at day and night time up to 2330 hours. We searched for amphibians in areas roughly $20 \mathrm{~m}$ on either sides of the track. In between walking to two neighbouring areas we paused for about 10 minutes to listen to amphibian calls.

We usually walked through prospective frog country and brushed over or lightly raked forest undergrowth and ground level vegetation with sticks and short poles to disturb the frogs. At night we listened to the calls and searched areas with miner's headlamps and battery operated spotlights. In most places we could not get any reading from our Garmin 75 GPS as the forest cover might have blocked us from satellite signals.

We collected a few specimens for taxonomical records and took photographs of the others and their habitats. Only five specimens of Occidozyga lima were preserved in formalin for further taxonomical studies. Other amphibians that had been caught were measured, photographed and released.

\section{Results and Discussion}

We covered $8 \mathrm{~km}$ of a $12-\mathrm{km}$ track that joins Whykeong Village $\left(21^{\circ} 06{ }^{\prime} 87^{\prime \prime N}\right.$ and $92^{\circ} 11^{\prime} 66^{\prime \prime E}$.) in the east with Shamlapur Village $\left(21^{\circ} 04^{\prime} 95^{\prime \prime} \mathrm{N}\right.$ and $92^{\circ} 07^{\prime} 66^{\prime E} \mathrm{E}$.) in the west. This track is partially covered with brick soling. It is heavily used by a locally improvised four-wheel drive jeep that can carry up to 24 passengers and nearly four tons of cargo! Also three-wheel auto-rickshaws ply this track when it is not under water. Occasionally lories transport grocery articles and construction material, fish, wood and paddy from one village to the other. In addition, we covered areas around Whykeong Village and the forests nearby. Our second site was Teknaf Town at 20 $53^{\prime} 17^{\prime \prime} \mathrm{N}$ and $92^{\circ} 17^{\prime} 93^{\prime \prime E}$. The third spot was Rajar Chhara, $5 \mathrm{~km}$ due northwest of Teknaf Town by the coast of Bay of Bengal.

Two sites were covered in Sylhet. One was in a less populated area of Sylhet town at Osmani Medical College Hospital compound, (24054'26"N and 91051'26"E.) with marshy area nearby and a patch of forest at Lohagarh Tilla by the outskirts of Sylhet Town, near 24053'88"N and 91054'26"E. We came across Occidozyga lima all along Whykeong-Shamlapur track that we covered, Whykeong forest village and the forest near Teknaf township. It is also present in Rajar Chhara area where we could not collect or photograph any specimen. No specimen was found or heard calling in Sylhet area.

Prospective $O$. lima habitats in Whykeong and Teknaf area had rather similar features of land and plant communities. This frog invariably occurred along the foothills on flatter ground bordering some permanent and temporary pools. The Puddle Frog also inhabited the forest clearings near the tracks and kuccha paths, which had temporary accumulations of water. By and large, these areas had at least two species of Colocasia as well as Alocasia sp., two species of grasses Ischaemum indicum and Chrysopogon aciculatus, one species of fern, Selaginella sp., Mikania scandens, Eupatorium odoratum, Cassia tora, Mimosa pudica, Clerodendron infortunatum, Polygonum sp., Melastoma sp., Mussaendra sp. and others.

The vegetation type where the Puddle Frog was found indicated that this species prefers forest clearings and edges rather than the actual forest. There must also be some accumulation of water nearby.

The habitat of the Puddle Frog was shared by an abundant population of Cricket Frog Limnonectes limnocharis and Skipping Frog Euphlyctis cyanophlyctis. Juveniles and subadults dominated these frog populations. In addition to these, there were frog-lets and juveniles of Indian Bull Frog Hoplobatrachus tigerinus. We also encountered a few 
specimens of Jerdon's Bull Frog Hoplobatrachus crassus and Common Toad Bufo melanostictus. All these were found during daytime observations.

During nighttime observations we came across the Puddle Frog, Cricket Frog, Skipping Frog, Ornate Narrow-mouthed Frog and Common Toad. Also we could hear Six-lined Tree Frog Polypedates leucomystax and Maculated or Indian Tree Frog Polypedates maculatus then. These were usually not heard or seen during daytime. The former preferred calling from objects above ground-level but the latter called from ground-level or from aquatic vegetation.

It was observed that during continuous daytime raining the Puddle Frog did not call. It called only at night, both at times of downpour and otherwise. The Narrow-mouthed Frog, Cricket Frog and Six-lined Tree Frog also called in similar situations. The Indian Bull frog called only during rainy period both at day and night. The Indian Tree Frog called both at day and night following rain. The Common Toad and Jerdon's Bull Frog called only at night both during rain and rainless period. We also heard Leaf Frog Rana erythraea from aquatic vegetation at night near Teknaf and Rajar Chhara.

Due to incessant rains and inundation, many specimens of Puddle Frog were found moving towards the upper sides of the inundated areas, where water level was low and there were temporary accumulation of water in small depressions. For the first time we noted a froglet, possibly of Six-lined Tree Frog, producing a single call-note 'tuc' or 'ták' that resembled the sound that is produced when two coins are pressed against each other. A froglet was collected when calling from an Arum leaf. It measured $22 \mathrm{~mm}$ in head and body length with an $8 \mathrm{~mm}$ long tail. We could hear froglets from various directions both at Whykeong and Raja Chhara.

I have modified my previous reporting of a call-note assigned to the Puddle (Bleating) Frog (Khan, 1997). This reporting was based on frogs calling from aquatic vegetation near the place of occurrence of Puddle Frog at Whykeong. Repeatedly pronounced sound "Khekko-khekko-khekko.." actually belongs to Polypedates maculatus. I became sure of it after catching a male frog that was calling repeatedly even when spotted with a spot-light. The Puddle Frog's long and breeding call resembles the bleating sound of a goat like 'baa-baa, baa..'

Snout to vent length of the Puddle Frog ranged from $21 \mathrm{~mm}$ to $25 \mathrm{~mm}$ with an average of $22.4 \mathrm{~mm}$ ( 4 samples). This is possibly the smallest of the frogs occurring in Bangladesh.

\section{Other fauna}

As for reptiles, during the entire observation period we came across only one Striped Keelback Amphiesma stolata but saw numerous Common Skinks Mabuya carinata and Garden Lizards Calotes versicolor. However, in human dwellings and grocery shops two species of House Geckos Hemidactylus frenatus and $H$. brookii were very common. We also saw Tockay Gecko Gekko gecko in several residential tin-sheds and on mud-walls.

Among mammals we saw Capped Langur Presbytis pileatus, Rhesus macaque Macaca mulatta, Irrawaddy Squirrel Callosciurus pygerythrus, Indian Flying Fox Pteropus giganteus, False Vampire Bat Megaderma lyra, Indian Pipistrelle Pipistrellus coromandra and Golden Jackal Canis aureus in the forested areas. In addition, we noted several species of rats and mice and House Shrew Suncus murinus in the villages.

Notable birds included Pied Hornbill Anthracoceros malabaricus, Bronze-winged Jacana Metopidius indicus, Little Cormorant Phalacrocorax niger, Pond Heron Ardeola grayii, Cattle Egret Bubulcus ibis, Little Egret Egretta garzetta, Large White Egret Egretta alba, Chestnut Bittern Ixobrychus cinnamomeus, Night Heron Nycticorax nycticorax, Brahminy Kite Haliastur indus, Shikra Accipiter badius, Spotted Owlet Athene brama, Brown Fish Owl Ketupa zeylonensis, Koel Euynamus scolopacea, Indian Cuckoo Cuculus micropternus, Brainfever Bird Cuculus varius, Crow-pheasant Centropus sinensis, Common Kingfisher Alcedo atthis, White-breasted Kingfisher Halcyon smyrnensis, Little Tern Sterna albifrons, Lineated Barbet Megalaima lineata, Coppersmith or Crimsonbreasted Barbet Megalaima haemacephala, Lesser Goldenbacked Woodpecker Dinopium benghalense, Little Scaly-bellied Green Woodpecker Picus myrmecophoneus, Himalayan Goldenbacked Three-toed Woodpecker Dinopium shorii, Fulvousbreasted Pied Woodpecker Picoides macei, and a few other Woodpeckers, Red-breasted Parakeet Psittacula alexandari, Rose-ringed Parakeet Psittacula krameri, and Loriket Loriculus vernalis, Grey-fronted Green Pigeon Treron pompadora, Green Pigeon Treron phoenicoptera, Green Imperial Pigeon Ducula aenea, Spotted Dove Streptopelia chinensis, Collared or Ring Dove Streptopelia decaocto, Red Turtle Dove Streptopelia tranquebarica, Little Green Bee-eater Merops orientalis and Palm Swift Cypsiurus balasiensis.

We also noted House Crow Corvus splendens, Jungle Crow Corvus macrorhynchus, Greater Racket-tailed Drongo Dicrurus pardiseus, Bronzed Drongo Dicrurus aeneus, Black Drongo Dicrurus adsimilis, Common and Jungle Myna Acridotheres tristis and A. fuscus, Pied Myna Sturnus contra, Grey-headed Myna Sturnus malabaricus, Scarlet Minivet Pericrocotus flammeus, Small Minivet P. cinnamommeus, Black-headed Shrike Lanius schach, Common Iora Aegithinia tiphia, White-eye Zosterops palpebrosa, Gold-fronted Chloropsis Chloropsis cochinchinensis, Franklin's Wren Warbler Prinia hodgsonii, Tailor Bird Orthotomus sutorius, Quaker Babbler Alcippe poioicephala, Spotted babbler Pellorneum ruficeps, Paradise 
Flycatcher Terpsiphone paradisi, Grey-headed Flycatcher Culicicapa ceylonensis, Ashy Swallow-shrike Artamus fuscus, Magpie Robin Copsychus saularis, Red-whiskered Bulbul Pycnonotus jocosus, Red-vented Bulbul Pycnonotus cafer, Blackheaded Bulbul Pycnonotus atriceps, Common or Barn Swallow Hirundo rustica, Little Spiderhunter Arachnothera longirostris, Tickell's Flowerpecker Dicaeum agile, Scarlet-backed Flowerpecker Dicaeum cruentatum, Purple-rumped Sunbird Nectarinia zeylonica, Purple Sunbird Nectarinia asiatica, Yellow-backed Sunbird Aethopyga siparaja, House Sparrow Passer domesticus and Baya Weaver Ploceus philippinus.

\section{Threats to Puddle Frog}

The small size of the Puddle Frog seems to protect it from direct human threat. Even species like Cricket and Skipping Frogs have not been killed for commercial exploitation. So, the major threat to the survival of this and related species is the loss of habitats either by transformation into cultivable land or the practice of monoculture of commercially important timber species. However, these threats are not critical but marginal for the Puddle Frog.

\section{Conclusion}

The present study established that Puddle (Bleating) Frog Occidozyga lima occurs patchily in the Teknaf Peninsula in Bangladesh, lending support to the earlier report of the species from one locality of the region. It also showed that this frog lives sympatrically with several other frogs and it does not occur in the Sylhet area of Bangladesh. However, areas having vegetation cover and topography similar to Teknaf Peninsula, e.g., mixed evergreen forests of the northern part of Cox's Bazar District, Chittagong, Parbottya Rangamati, Bandarban and Khagra Chhari should be prospected for its further occurrence.

\section{Acknowledgements}

I wish to thank Dr. Richard J. Hornby, Chairman, and Emirates Natural History Group for taking an interest in the project and the ENHG for providing financial assistance to partly cover the cost of the project. Thanks go to my wife Nazu and sister-in-law Mrs. Nurul Akhter, MD of Chemico Laboratories, Dhaka for financing my Sylhet trip. I am extremely thankful to Mohammad Mohsinuzzaman Chowdhury - an energetic, young amphibian biologist based at Dhaka, for helping me in my field trip to Teknaf, Mr. Zafar Alam Choudhury of Whykeong for his hospitality, Bangladesh Government Forest Department, especially Divisional Forest Officer at Cox's Bazar, for permitting me to stay at their rest house in Teknaf and Range Officers at Whykeong and Teknaf for local assistance. Thanks also go to Messrs. Anisuzzaman Khan, Programme Officer of IUCN, and Manzurul Hannan Khan, National Conservation Strategy, PhaseII, Government of Bangladesh and Mr. Nazrul Haque, Curator, National Museum for their advice and various help. Thanks are also due to Azizur Rahman, Yusuf Ali, Muhammadullah, Sona Miah, Nuru Miah, Nurur Salam, Mohammad Ibrahim, Mohammad Azizur and Master Disha for assisting me in fieldwork at Whykeong, Teknaf, Rajar Chhara and Sylhet.

\section{References}

Chowdhury, M. (1996). The amphibians of Bangladesh. Froglog (19): 1-2.

Deuti, K. and B.C. Bharathi-Goswami (1995). A Field-Guide to the Amphibians of West Bengal Plains. World Wide Fund for Nature- India (Eastern region), Calcutta.

Husain, K.Z. and M.M. Rahman (1978). The amphibian fauna of Bangladesh. Bangladesh Journal of Zoology 6(2): 157-158.

Khan, M.A.R. (1982). Wildlife of Bangladesh - a checklist. Dhaka University, Bangladesh, 173 pp.

Khan, M.A.R. (1987). Bangladesher Bonnyaprani. Vol. 1. Wildlife of Bangladesh: Amphibia to Reptilia (in Bengali). Bangla Academy, Dhaka, $169 \mathrm{pp}$.

Khan, M.A.R. (1997). First record of Occidozyga lima (Gravenhorst, 1829) from Bangladesh. Hamadryad 22(2): 129-130. 